JURNAL PENDIDIKAN, p-ISSN 2715-095X, e-ISSN 2686-5041

Volume 29, No.2, Juli 2020 (169-176)

Online: http://journal.univetbantara.ac.id/index.php/jp

\title{
Pelaksanaan Pendidikan Karakter Melalui Gerakan Pramuka di Era Pandemi Covid 19
}

\author{
Suyahman \\ Dosen Program Studi PPKn, Fakultas Keguruan dan Ilmu Pendidikan \\ Universitas Veteran Bangun Nusantara Sukoharjo,Email: suyahman.suyahman@yahoo.com
}

\begin{abstract}
Abstrak: Penelitian ini bertujuan untuk mendeskripsikan pelaksanaan pendidikan karakter melalui gerakan pramuka di era pandemic covid19 yang dikaji secara teoritis dan praktis. Jenis penelitian ini adalah penelitian kepustakaan. Subjek penelitiannya adalah pelaksanaan pendidikan karakter di dalam gerakan pramuka, dan objek penelitiannya adalah Gerakan pramuka. Pengumpulan data dilakukan melalui: analisis buku-buku, laporan penelitian, makalah, artikel, dan skripsi, thesis serta sumber-sumber lainnya yang berkaitan dengan materi yang diteliti. Teknik analisis data dilakukan dengan teknik analisis interaktif. Aktifitas analisis data model ini antara lain, reduksi data, display data dan gambaran konklusi atau verifikasi. Hasil penelitian: berdasarkan hasil analisis literature dari buku-buku pustaka diantaranya Bukubuku tentang pendidikan karakter, artikel tentang pendidikan karakter, makalah tentang pendidikan karakter, laporan hasil penelitian tentang pendidikan karakter, AD dan ART Gerakan Pramuka, UU nomor 10 tentang Gerakan Pramuka, SKB tentang pelaksanaan bela Negara melalui gerakan pramuka diperoleh informasi bahwa pelaksanaan pendidikan karakter khususnya nilai karakter: religius, kepedulian, tanggung jawab, melalui gerakan pramuka di era pandemic covid 19 dilakukan dengan menggunakan metode: menyanyi lagu-lagu yang bernuansa religius, kepedulian dan nasionalisme yang dilakukan secara online dengan menggunakan aplikasi google classroom, sedangkan untuk nilai karakter: nasionalisme, disiplin dan demokrasi dilakukan dengan menggunakan media video yang di dalamnya memuat nilainilai tersebut yang dilakukan secara online dengan aplikasi Whattsap. Kesimpulannya bahwa pelaksanaan pendidikan karakter religius, kepedulian, kemandirian, tanggung jawab, disiplin, nasionalisme, dan demokrasi dalam gerakan pramuka di era pandemic covid 19 dilakukan dengan menggunakan metode menyanyi, serta dengan video yang menceritakan tentang nilai karakter disiplin, mandiri, nasionalisme, dan demokrasi yang dilakukan secara online dengan aplikasi WA dan google class room.
\end{abstract}

Kata-Kata Kunci: Pendidikan karakter dan Gerakan Pramuka

\section{Implementation Of Character Education Through The Scout Movement In The Covid Pandemic Era 19}

\author{
Suyahman \\ Lecturer of PPKn Study Program, Faculty of Teacher Training and Education \\ Bangun Nusantara Sukoharjo Veterans University, Email: suyahman.suyahman@yahoo.com
}

Abstract: This study aims to describe the implementation of character education through the scouting movement in the era of the pandemic covid19, which was studied theoretically and practically. This type of research is library research. The subject of his research was the implementation of character education in the scout movement, and the object of his research was the Scout Movement. Data collection is done through: analysis of books, research reports, papers, articles, and theses, theses and other sources related to the material under study. Data 
analysis technique is done by interactive analysis techniques. The data analysis activities of this model include, among others, data reduction, data display and conclusion or verification. Research results: based on the results of literature analysis from literature books including books on character education, articles on character education, papers on character education, reports on research results on character education, AD and ART Scout Movement, Law number 10 on the Scout Movement, The Joint Decree on the implementation of the defense of the State through the scout movement obtained information that the implementation of character education in particular the character values: religious, caring, responsibility, through the scouting movement in the pandemic covid era 19 was carried out using the method: singing songs that had religious nuances, caring and nationalism which done online using the google classroom application, while for the value of character: nationalism, discipline and democracy is done using video media which contains these values which are done online with the Whattsap application. The conclusion is that the implementation of religious character education, care, independence, responsibility, discipline, nationalism, and democracy in the scouting movement in the pandemic covid era 19 is done using the singing method, as well as with videos that tell the values of the character of discipline, independence, nationalism, and democracy which is done online with the WA application and google class room.

Key Words: Character education and the Scout Movement

\section{Pendahuluan}

Pandemi covid 19 memiliki dampak pada semua sector kehidupan manusia di segala aspek dan bidangnya. Dalam dunia pendidikan dampak pandemic covid 19 berada pada pelaksanaan kegiatan akademik yakni yang semula dilakukan tatap muka/luring sekarang dilakukan secara online/daring. Pelaksanaan kegiatan akademik secara online dimaksudkan untuk meminimalisir atau memutus mata rantai penuliran virus covid 19 . Guna mendukung kegiatan ini pemerintah membuat kebijakan protocol kesehatan pada semua manusia dalam melakukan aktivitas kehidupannya. Kata karakter berasal dari bahasa Latin "Karakter", "Kharassein", "Kharax", dalam bahasa Inggris "Character" dan Indonesia "Karakter", Yunani "Character", dari charassein yang berarti membuat tajam, membuat dalam. Dalam kamus poerwadarminta, karakter diartikan sebagai tabiat, watak, sifat-sifat kejiwaan, akhlak atau budi pekerti yang membedakan seseorang dengan yang lain, nama dari jumlah seluruh ciri pribadi yang meliputi hal-hal seperti perilaku, kebiasaan, kesukaan, ketidaksukaan, kemampuan, kecenderungan, potensi, nilai-nilai, dan pola-pola pemikiran. Menurut UU Sistem Pendidikan Nasional No. 20 tahun 2003 Pasal 1 butir 1, pendidikan adalah usaha sadar dan terencana untuk mewujudkan suasana belajar dan proses pembelajaran agar peserta didik secara aktif mengembangkan potensi dirinya untuk memiliki kekuatan spiritual keagamaan, pengendalian diri, kepribadian, kecerdasan, akhlak mulia, serta keterampilan yang diperlukan dirinya, masyarakat, bangsa dan negara. Pendidikan nasional bertujuan untuk mengembangkan potensi peserta didik agar menjadi manusia yang beriman dan bertakwa kepada Tuhan Yang Maha Esa, berakhlak mulia, sehat, berilmu, cakap, kreatif, mandiri dan menjadi warga negara yang demokratis serta bertanggung jawab.

Adapun pendidikan karakter didefinisikan oleh Hornby dan Parnwell, yang mengatakan karakter adalah kualitas mental atau moral, nama atau reputasi. Hermawan Kertajaya mendefinisikan karakter adalah ciri khas yang dimiliki oleh suatu benda atau individu. Ciri khas tersebut ialah asli dan mengakar pada kepribadian benda atau individu tersebut dan merupakan mesin pendorong bagaimana seseorang bertindak, bersikap, berujar, dan 
merespons sesuatu. Menurut T. Ramli (2003) pendidikan karakter memiliki esensi dan makna yang sama dengan pendidikan moral dan pendidikan akhlak. Tujuannya adalah untuk membentuk membentuk pribadi anak supaya menjadi manusia yang baik, warga masyarakat dan warga negara yang baik. Sementara itu Suyanto (2009) Mengemukakan pendidikan karakter sebagai cara berpikir dan berperilaku yang menjadi ciri khas tiap individu untuk hidup dan bekerja sama, baik dalam lingkup keluarga, masyarakat, bangsa, maupun negara. John W. Santrock berpendapat Pendidikan karakter merupakan pendekatan langsung untuk pendidikan moral dengan memberi pelajaran kepada peserta didik tentang pengetahuan moral dasar untuk mencegah mereka melakukan perilaku tidak bermoral atau membahayakan bagi diri sendiri maupun orang lain. Perkembangan IPTEK yang tidak selektif dan tidak terkendali berdampak menggerus nilai-nilai karakter anak bangsa. Karena itu maka pendidikan akrakter manjadi prioritas untuk dikedepankan pelaksanaannya. Seperti kita ketahui bahwa proses globalisasi secara terus-menerus akan berdampak pada perubahan karakter masyarakat Indonesia. Kurangnya pendidikan karakter akan menimbulkan krisis moral yang berakibat pada perilaku negatif di masyarakat, misalnya; pergaulan bebas, penyalahgunaan obat-obat terlarang, pencurian, kekerasan terhadap anak, dan lain sebagainya. Menurut Thomas Lickona, setidaknya ada tujuh alasan mengapa character education harus diberikan kepada warga negara sejak dini, yaitu; Ini merupakan cara paling baik untuk memastikan para murid memiliki kepribadian dan karakter yang baik dalam hidupnya. Pendidikan ini dapat membantu meningkatkan prestasi akademik anak didik. Sebagian anak tidak bisa membentuk karakter yang kuat untuk dirinya di tempat lain. Dapat membentuk individu yang menghargai dan menghormati orang lain dan dapat hidup di dalam masyarakat yang majemuk. Sebagai upaya mengatasi akar masalah moral-sosial, seperti ketidakjujuran, ketidaksopanan, kekerasan, etos kerja rendah, dan lain-lain. Merupakan cara terbaik untuk membentuk perilaku individu sebelum masuk ke dunia kerja/ usaha. Sebagai cara untuk mengajarkan nilai-nilai budaya yang merupakan bagian dari kerja suatu peradaban.

Pada dasarnya tujuan utama pendidikan karakter adalah untuk membangun generasi bangsa yang tangguh, di mana masyarakatnya berakhlak mulia, bermoral, bertoleransi, dan bergotong-royong. Untuk mencapai tujuan tersebut maka di dalam diri peserta didik harus ditanamkan nilai-nilai pembentuk karakter yang bersumber dari Agama, Pancasila, dan Budaya. Berikut adalah nilai-nilai pembentuk karakter menurut kemendiknas tersebut: Kejujuran Sikap toleransi, Disiplin, Kerja keras, Kreatif, Kemandirian, Sikap demokratis, Rasa ingin tahu, Semangat kebangsaan, Cinta tanah air, Menghargai prestasi, Sikap bersahabat, Cinta damai, Gemar membaca, Perduli terhadap lingkungan, Perduli social, Rasa tanggungjawab dan Religius. Di Indonesia, berdasarkan Perpres No. 87 Tahun 2017 tentang Penguatan Pendidikan karakter (PPK) fokus pada lima nilai karakter utama yang bersumber dari Pancasila, yaitu: Penerapan nilai karakter religius dalam kehidupan masyarakat Indonesia sehari-hari dapat terlihat dalam beberapa hal, di antaranya; Sikap cintai damai. Sikap toleransi. Menghargai perbedaan agama dan kepercayaan. Berpendirian teguh. Percaya diri. Kerja sama antar pemeluk agama dan kepercayaan. Anti terhadap perundungan dan kekerasan. Mencintai lingkungan dan Dan lain sebagainya.

Nilai karakter nasionalis merupakan cara berpikir, bersikap, dan bertindak yang menunjukkan kesetiaan, kepedulian, dan penghargaan terhadap bahasa, lingkungan, sosial, budaya, dan politik bangsa. Penerapan nilai karakter nasionalis dalam kehidupan masyarakat sehari-hari dapat terlihat dalam beberapa hal, di antaranya; Apresiasi terhadap budaya Indoenesia. Menjaga kekayaan budaya Indonesia. Cinta tanah air dan Menghormati 
keberagaman budaya, suku, dan, agama. Nilai karakter integritas merupakan nilai yang menjadi dasar perilaku setiap individu sehingga individu tersebut dapat dipercaya dalam perkataan dan perbuatan, serta berkomitmen terhadap moral dan nilai-nilai kemanusiaan. Penerapan nilai karakter integritas dalam kehidupan masyarakat sehari-hari dapat terlihat dalam beberapa hal, di antaranya; Sikap bertanggungjawab. Aktif terlibat dalam kehidupan social dan Konsisten dalam perkataan dan perbuatan yang berdasarkan kebenaran. Nilai karakter mandiri merupakan sikap dan perilaku yang tidak tergantung pada orang lain dalam kehidupannya. Dengan kata lain, individu yang mandiri akan mempergunakan pikiran, tenaga, dan waktunya untuk mewujudkan harapan dan cita-citanya. Penerapan nilai karakter mandiri dapat terlihat dalam beberapa hal, di antaranya; Memiliki etos kerja yang baik. Memiliki daya juang yang tinggi. Tangguh dalam menghadapi tanangan dan Memiliki keberanian dan kreatif dalam bertindak. Nilai karakter gotong-royong merupakan sikap dan perilaku yang menghargai semangat kerja sama dan bahu membahu dalam menyelesaikan masalah bersama.

Penerapan nilai karakter gotong-royong dapat terlihat dalam beberapa hal, di antaranya; Menghargai sesama. Dapat bekerjasama. Mampu berkomitmen terhadap keputusan bersama. Saling tolong menoling. Rasa solidaritas dan sikap kerelawanan dan Anti terhadap diskriminasi dan kekerasan. Secara umum fungsi pendidikan ini adalah sebagai pembentuk karakter peserta didik sehingga menjadi pribadi yang bermoral, berakhlak mulia, bertoleran, tangguh, dan berperilaku baik. Adapun beberapa fungsi pendidikan karakter adalah sebagai berikut; Untuk mengembangkan potensi dasar dalam diri manusia sehingga menjadi individu yang berpikiran baik, berhati baik, dan berperilaku baik. Untuk membangun dan memperkuat perilaku masyarakat yang multikultur. Untuk membangun dan meningkatkan peradaban bangsa yang kompetitif dalam hubungan internasional. Character education seharusnya dilakukan sejak dini, yaitu sejak masa kanak-kanak. Pendidikan ini bisa dilakukan di lingkungan keluarga, sekolah, dan lingkungan, serta memanfaatkan berbagai media belajar. Pendidikan karakter bukanlah sesuatu yang baru. Sebetulnya pendidikan karakter sama tuanya dengan pendidikan itu sendiri. Sepanjang sejarah, di negara-negara seluruh dunia, pendidikan memiliki dua tujuan besar yakni membantu anak-anak menjadi pintar dan membantu mereka menjadi baik. Sejak zaman Plato, pendidikan karakter yang dibarengkan dengan pendidikan intelektual, kesusilaan, dan literasi, serta budi pekerti dan kemanusiaan. Mereka mencoba membentuk sebuah masyarakat yang menggunakan kecerdasan mereka untuk kemaslahatan orang lain dan diri mereka, yang akan mencoba membangun dunia yang lebih baik.

Begitu urgennya pendidikan karakter maka dalam pelaksanaannya menjadi tanggung jawab bersama antara keluarga, sekolah dan masyarakat. Di era pandemic covid 19 saat ini pelaksanaan pendidikan karakter tidak dapat maksimal karena bagaimanapun juga pendidikan karakter tidak hanya sekedar di ucapkan akan tetapi harus dipahami, diyakini dan di amalkan dalam bentuk sikap dan keteladanan. Guna mewujudkan pelaksanaan pendidikan karakter yang lbih luas maka pemerintah memberikan kepercayaan pada organisasi-organisasi keagamaan, kemasyarakatan, social politik, organisasi profesi serta organisasi kepemudaan. Gerakan pramuka sebagai bagian dari organisasi kemasyarakatan tergerak untuk secara aktif dan kreatis melakukan pendidikan kepramukaan sesuai dengan jenjang, jenis dan usia peserta didik. Gerakan pramuka sebagai organisasi kemasyarakatan memiliki visi, misi, strategi dan tujuan sebagai berikut: Visi: "Gerakan Pramuka sebagai wadah pilihan utama dan solusi handal masalah kaum muda", dan Misinya adalah: Mempramukakan kaum muda Membina anggota yang berjiwa dan 
berwatak pramuka, berlandaskan iman dan taqwa, serta selalu mengikuti perkembangan ilmu pengetahuan dan teknologi. Membentuk kader bangsa patriot pembangunan yang memiliki jiwa bela Negara Menggerakan anggota dan organisasi Gerakkan Pramuka agar peduli dan tanggap terhadap masalah-masalah kemasyarakatan. Dalam upaya mewujudkan visi dan misinya Gerakan pramuka menyusun strategi sebagai berikut: Meningkatkan jumlah dan mutu satuan pendidikan keparamukaan, Meningkatkan jumlah dan mutu peserta didik, Meningkatkan jumlah dan mutu tenaga pendidik, Memperbarui kurikulum pendidikan kepramukaan, Meningkatkan sarana dan prasarana Pendidikan, Memantapkan organisasi, sitem manajemen, dan sumber daya dan Meningkatkan pelaksanaan pelbagai program Gerakan Pramuka. Tujuan Gerakan Pramuka sebagai penyelenggara pendidikan kepanduan Indonesia yang merupakan bagian pendidikan nasional, bertujuan untuk membina kaum muda dalam mencapai sepenuhnya potensi-potensi spiritual, social, intelektual dan fisiknya, agara mereka bias: Membentuk, kepribadian dan akhlak mulia kaum muda, Menanamkan semangat kebangsaan, cinta tanah air dan bela negara bagi kaum muda, Meningkatkan keterampilan kaum muda sehingga siap menjadi anggota masyarakat yang bermanfaat, patriot dan pejuang yang tangguh, serta menjdai calon pemimpin bangsa yang handal pada masa depan.

\section{Metode Penelitian}

Jenis penelitian ini adalah studi kepustakaan. Studi kepustakaan dapat diartikan sebagai suatu langkah untuk memperoleh informasi dari penelitian terdahulu yang harus dikerjakan, tanpa memperdulikan apakah sebuah penelitian menggunakan data primer atau data sekunder, apakah penelitian tersebut menggunakan penelitian lapangan ataupun laboratorium atau didalam museum. Pengertian studi kepustakaan menurut M. Nazir dalam bukunya yang berjudul Metode Penelitian, mengemukakan bahwa yang dimaksud dengan studi kepustakaan adalah teknik pengumpulan data dengan mengadakan studi penelaahan terhadap buku-buku, literatur-literatur, catatan-catatan, dan laporan-laporan yang ada hubungannya dengan masalah yang dipecahkan. Selanjutnya menurut Nazir studi kepustakaan merupakan langkah yang penting dimana setelah seorang peneliti menetapkan topik penelitian, langkah selanjutnya adalah melakukan kajian yang berkaitan dengan teori yang berkaitan dengan topik penelitian. ${ }^{1[2]}$ Dalam pencarian teori, peneliti akan mengumpulkan informasi sebanyak-banyaknya dari kepustakaan yang berhubungan. Sumber-sumber kepustakaan dapat diperoleh dari: buku, jurnal, majalah, hasil-hasil penelitian, dan sumber-sumber lainnya yang sesuai (internet, koran dan lain lain). Bila kita telah memperoleh kepustakaan yang relevan, maka segera untuk disusun secara teratur untuk dipergunakan dalam penelitian. Oleh karena itu studi kepustakaan meliputi proses umum seperti: mengidentifikasikan teori secara sistematis, penemuan pustaka, dan analisis dokumen yang memuat informasi yang berkaitan dengan topik penelitian. Pandangan lain Noeng Muhadjir (1996:169) menjelaskan Penelitian kepustakaan yaitu penelitian yang lebih memerlukan olahan filosofis dan teoritis daripada uji empiris dilapangan. Karena sifatnya yang teoritis dan filosofis, penelitian kepustakaan lebih sering menggunakan pendekatan filosofis dibandingkan pendekatan yang lain. Metode penelitian kepustakaan mencakup sumber data, pengumpulan data, dan analisis data. Demikian juga dengan 
Mardalis menegaskan Penelitian kepustakaan dapat didefinisikan sebagai penelitian yang bertujuan untuk mengumpulkan data dan informasi melalui bantuan bermacam-macam material yang terdapat di ruangan perpustakaan, misalnya: buku-buku, majalah, dokumen, catatan dan kisah-kisah sejarah dan lain-lainnya.

Penelitian kepustakaan memiliki empat ciri utama, yaitu: Peneliti berhadapan langsung dengan teks (nash) atau data angka dan bukan dengan pengetahuan langsung dari lapangan atau saksi mata (eyewitness) yang berupa kejadian,orang atau benda-benda lainnya. Data pustaka bersifat 'siap pakai' (ready made). Ini artinya yaitu peneliti tidak pergi kemana mana, kecuali hanya berhadapan langsung dengan bahan sumber yang sudah tersedia di perpustakaan. Data pustaka umumnya berupa sumber sekunder, yang berarti bahwa peneliti mendapatkan bahan dari tangan kedua dan bukan data orisinil dari tangan pertama di lapangan. Kondisi data pustaka tidak dibatasi oleh ruang dan waktu. Peneliti berhadapan dengan informasi statis, tetap. Macam-macam penelitian kepustakaan, antara lain: Kajian Pemikiran Tokoh, Analisis Buku Teks, dan Kajian Sejarah. Dalam penelitian ini digunakan jenis Analisis Buku Teks Buku teks yang dimaksud dalam hal ini menakup buku pelajaran (SD, MI, SMA, MA, SMK, dan buku-buku referensi di perguruan tinggi). Penelitian berbasis analisis buku teks terhadap buku-buku pelajaran disekolah biasanya bersifat evaluasi guna mengukur relevansi materi pelajaran dengan perkembangan mutakhir. Sedangkan penelitian kepustakaan terhadap buku-buku referensi diperguruan tinggi lebih bersifat pengembangan atau implementasi teori yang telah ada, dan relevansinya dengan perkembangan zaman sekarang. Metode pengumpulan data yang digunakan yaitu dokumentasi yang dilakukan dengan menganalisis buku-buku, laporan penelitian, makalah, artikel, dan skripsi, thesis serta sumber-sumber lainnya yang berkaitan dengan materi yang diteliti. Teknik analisis data dilakukan dengan teknik analisis interaktif. Aktifitas analisis data model ini antara lain, reduksi data, display data dan gambaran konklusi atau verifikasi.

\section{Hasil Penelitian}

Berdasarkan analisis pendidikan karakter di era pandemic covid 19 dapat ditemukan hal-hal sebagai berikut: pertama bahwa pendidikan karakter muaranya adalah membentuk sikap, perilaku dan tindakan yang baik yakni yang sesuai dengan kepribadian bangsa indoneisa. Tindakan yang baik sesuai dengan kepripadian bangsa Indonesia memiliki ruang lingkup 18 nilai karakter yaitu: Kejujuran Sikap toleransi, Disiplin, Kerja keras, Kreatif, Kemandirian, Sikap demokratis, Rasa ingin tahu, Semangat kebangsaan, Cinta tanah air, Menghargai prestasi, Sikap bersahabat, Cinta damai, Gemar membaca, Perduli terhadap lingkungan, Perduli social, Rasa tanggungjawab dan Religius. Melihat begitu luas cakupan pendidikan karakter, maka pemerintah melalui Perpres No. 87 Tahun 2017 tentang Penguatan Pendidikan karakter (PPK) fokus pada lima nilai karakter utama yang bersumber dari Pancasila, yaitu: Nilai Karakter Nasionalis, Nilai Karakter Integritas, Nilai Karakter Mandiri, Nilai Karakter Gotong Royong. Nilai karakter baik menurut kemendikbud ada 18 maupun menurut Perpres No. 87 Tahun 2017 tentang Penguatan Pendidikan karakter (PPK) fokus pada lima nilai karakter utama secara ksplisit sudah di akomodir dalam gerakan pramuka yang dituangkan dalam tri satya dan dasa darma gerakan pramuka. Tri satya berisi:

Demi kehormatanku aku berjanji akan bersungguh-sungguh: (1).menjalankan kewajibanku terhadap tuhan yang maha esa dan negara kesatuan republik indonesia, dan menjalankan pancasila. (2). menolong sesama hidup dan ikut serta membangun masyarakat. 
(3).menepati dasa dharma. Dasa dharma sebagai ketentuan moral bagi anggota pramuka berisi: (1). Takwa kepada Tuhan Yang Maha Esa. (2). Cinta alam dan kasih sayang sesama manusia. (3). Patriot yang sopan dan ksatria. (4). Patuh dan suka bermusyawarah. (5). Rela menolong dan tabah. (6). Rajin, terampil, dan gembira. (7). Hemat, cermat, dan bersahaja. (8). Disiplin, berani, dan setia. (9). Bertanggung jawab dan dapat dipercaya, dan (10). Suci dalam pikiran, perkataan, dan perbuatan. Pelaksanaan pendidikan karakter melalui gerakan pramuka mengacu pada substansi Tri satya dan dasa Darma Pramuka artinya bahwa semua kegiatan kepramukaan harus mencerminkan Tri Satya dan dasa darma.

\section{Pembahasan}

Pendidikan karakter bukanlah sesuatu yang baru. Sebetulnya pendidikan karakter sama tuanya dengan pendidikan itu sendiri. Sepanjang sejarah, di negara-negara seluruh dunia, pendidikan memiliki dua tujuan besar yakni membantu anak-anak menjadi pintar dan membantu mereka menjadi baik. Sejak zaman Plato, pendidikan karakter yang dibarengkan dengan pendidikan intelektual, kesusilaan, dan literasi, serta budi pekerti dan kemanusiaan. Mereka mencoba membentuk sebuah masyarakat yang menggunakan kecerdasan mereka untuk kemaslahatan orang lain dan diri mereka, yang akan mencoba membangun dunia yang lebih baik. Adapun tujuan pendidikan karakter menurut Kementerian Pendidikan Nasional adalah mengembangkan karakter peserta didik agar mampu mewujudkan nilai-nilai luhur Pancasila. Apabila tujuan pendidikan karakter yang berbasis agama dan bangsa, maka tujuannya ialah menanamkan jiwa kepemimpinan dan tanggung jawab peserta didik sebagai generasi penerus bangsa, mengembangkan kemampuan peserta didik menjadi manusia yang mandiri, kreatif dan berwawasan kebangsaan, mengembangkan lingkungan kehidupan sekolah sebagai lingkungan belajar yang aman, jujur, penuh kreativitas dan persahabatan, serta dengan rasa kebangsaan yang tinggi dan penuh kekuatan. Pada prinsipnya, pengembangan budaya dan karakter bangsa tidak dimasukkan sebagai pokok bahasan tetapi terintegrasi ke dalam mata pelajaran, pengembangan diri, dan budaya sekolah. Oleh karena itu, guru dan sekolah perlu mengintegrasikan nilai-nilai yang dikembangkan dalam pendidikan budaya dan karakter bangsa ke dalam Kurikulum Tingkat Satuan Pendidikan 2006 (KTSP) atau Kurikulum 2013 (Kurtilas), Silabus, dan Rencana Program Pembelajaran (RPP) yang sudah ada.

Berikut prinsip-prinsip yang digunakan dalam pengembangan pendidikan budaya dan karakter bangsa yang meliputi: Pendidikan merupakan kiat untuk menerapkan prinsipprinsip ilmu pengetahuan dan teknologi bagi manusia. Pendidikan merupakan proses interaksi sesama manusia yang ditandai keseimbangan antara kedaulatan subjek didik dengan kewibawaan pendidik, Pendidikan pada prinsipnya berlangsung seumur hidup, Pendidikan merupakan upaya mensiapkan peserta didik menghadapi lingkungan yang mengalami perubahan semakin besar., Pendidikan meningkatkan kualitas kehidupan pribadi dan masyarakat.Mengacu pada konsep pendidikan karakter, fungsi, tujuan, cakupan nilai karakter, prinsip-prinsip pendidikan karakter jika di padukan dengan visi, misi, strategi, tujuan, materi pendidikan kepramukaan maka dapat dijelsakan sebagai berikut.

Dalam kaitannya dengan pelaksanaan pendidikan karakter melalui gerakan pramuka di era covid 19. Yang perlu dipegang adalah bahwa pelaksanaannya dilakukan secara daring sesuai kebijakan pemerintah. Pelaksanaan pendidikan karakter melalui gerakan pramuka dilakukan dengan menggunakan metode cwramah serta diskusi dan Tanya jawab dengan aplikasi WA dan Video call. Target nilainya adalah nilai religius, nilai disiplin nilai 
tanggung jawab dan nilai kepedulian. Selain itu juga dilakukan melalui Video yang berisi ceritera-ceritera yang mencerminkan sikap kepedulian, kerja sama, nasionalisme dan demokrasi dengan menggunakan aplikasi google class room target nilai karakternya adalah kepedulian, kerja sama, nasionalisme dan demokrasi.

\section{Simpulan dan Saran}

Pelaksanaan pendidikan karakter dalam gerakan pramuka di era pandemic covid 19 yang dilaksanakan secara daring sesuai dengan kebijakan pemerintah guna memutus mata rantai penyebaran virus covid 19 dirasakan kurang maksimal karena target nilai yang diharapkan kurang maksimal.

\section{Daftar Rujukan}

Departemen Pendidikan dan Kebudayaan (2010). Pembinaan Pendidikan Karakter di Sekolah Menengah Pertama. Jakarta: Kemendiknas.

Gunanjar Ari Agustian. (2006). Rahasia Membangkitkan emosional Spiritual Quetiont Power, Jakarta : Arga.

Hasan, S. Hamid. (2000). Pendekatan Multikultural untuk Penyempurnaan Kurikulum, Bandung: Remaja Rosdakarya.

Heri Gunawan. (2012). Pendidikan Karakter, (Konsep dan Implementasi), Bandung : Alfabeta.

Joko Mursitho. (2019). Panduan pelaksanaan pendidikan karakter melalui gerakan pramuka, makalah tidak dipublikasikan

Kwartir Nasional Gerakan Pramuka. (2018). AD dan ART Gerakan Pramuka. Jakarta: jalan Merdeka Timur

Kwartir Nasional Gerakan Pramuka. (2010). UU Nomor 10 tahun 2012, Gerakan Pramuka : Jakarta: jalan Merdeka Timur

Majid Abdul. (2010). Pendidikan karakter dalam perspektif Islam, Bandung : Remaja Rosdakarya.

Munir Abdullah. (2010). Pendidikan Karakter, Yogyakarta: Pedagogia.

Trianto. (2009). Pembelajaran Inovatif Berorientasi Konstruktivistik, Jakarta: Prestasi Pustaka Publisher.

Virsya Norla. (2011). Panduan Menerapkan Pendidikan karakter Di sekolah, Jakarta:Laksana. 